\title{
Pre-/Post-traumatic Stress Symptoms of Qanun Defendants: A Case Report
}

\author{
Cut N. Dian, Elmeida Effendy* (D), Mustafa M. Amin (D) \\ Department of Psychiatry, Faculty of Medicine, Universitas Sumatera Utara, Medan, Indonesia
}

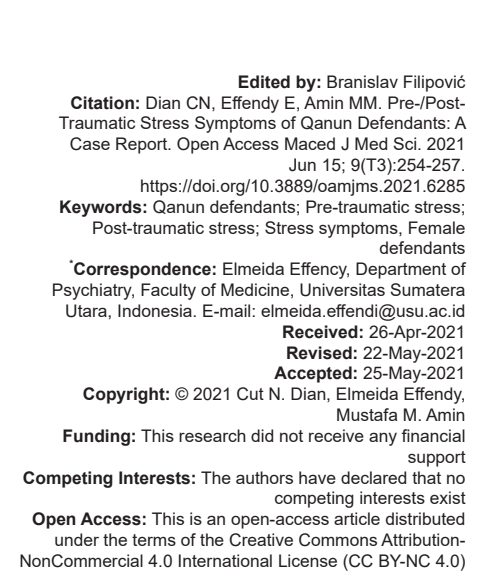

Abstract

BACKGROUND: Caning sentence has been applied for over a decade which is performed publicly. Given that emotional features of the defendants of the caning sentence occur, psychological symptoms may have emerged. One of the executions for the defendants is whipping practice that resembles military punishment, in which the penalty could have affected their personality pre and post-execution.

CASE REPORT: In this report, a 30-year-old married woman was sentenced to Qanun criminal offense in Aceh due to her despicable relationship to a male individual who is also a husband of someone. As the caning regulation stated that the punishment execution must be performed through whipping in public places, the women demonstrated several mental conditions such as anxiety, sleeping disorders, and unmotivated in the last 3 days before execution.

CONCLUSION: Caning practice in Aceh is performed by following the guidance from a medical doctor to prevent unexpected physical damage; however, psychological symptoms that could last for several years in the future might have occurred. Thus, a high prevalence of mental disorders has appeared among the defendants.

\section{Introduction}

Caning sentence, particularly in Nanggroe Aceh Darussalam (NAD) Province in Indonesia, is a set of constitutional law given by the central government due to the special status of this province for the practices of Islamic Sharia. Technically speaking, the practice of caning sentence is based on the Islamic legal that its establishment is originated from the Quran and Hadith of Prophet Muhammad Be Peace upon Him. This sentence is a local regulation issued by the Aceh People's Representative Council (DPRA), based on the special regency of NAD on the number of $18 / 2001$ concerning the special autonomy to the province [1]. The caning sentence is commonly known as Qanun law.

The NAD Province, the only province in Indonesia, implements the Sharia Islamic Law. This law refers to the provisions of Islamic criminal law that is based on Aceh Qanun No. 6/2014 concerning the Jinayat Law. Interestingly, although the Indonesian constitutional laws continue to be applied in this province, the local government is allowed to use some additional regulations that are originated from the Islamic criminal law. As its privileges in combining both national and Islamic rules, some violations such as production, distribution, and consumption of alcoholic beverages, gambling, adultery and marital adultery, and Lesbian, Gay, Bisexual and Transexual acts are prohibited [2]. Thus, everyone who violates the law is prosecuted under this law by caning, fines, or imprisonment.

The Indonesian people are communal people full of traditions. Several traditions might have violated the Qanun law such as how to dress, behave, and things in society. Despite these regulations, Acehnese is very receptive to the differences between fellow religious believers that are indicated by respecting the others. However, sometimes, punishment such as caning is not being accepted by several people as the sins that are caused by someone's action belong to his relationship to God. This implies to no rights of the state in providing the punishment. As a result, some people believe that caning is unfair, which leads to psychological symptoms, and those are including anxiety and depression [3], [4], [5].

\section{Case Report}

A 30-years-old of Acehnese married woman who had two children was caught by local society 
during mating with someone. This man was initially known as a husband who has married the other woman. According to his statement, this marital affair has been carried out frequently as both of them are in favor; however, at this moment, they were apprehended.

The affair was started through social media. The woman initially communicated, and this communication has lasted for 1 month which improves their intense known. Then, both of them are interested in each other as they often do video calls which have been followed by "video call of sex." Since the husband of the woman serves in out-of-town, the first meeting was conducted in her house. With these frequent meetings, suspicion among people in the neighborhood increased, which led them to investigate the house. As a result, they were caught by the communal people who were taken to the Special Corps of Islamic Sharia. Therefore, they were imprisoned for 3 months as well as sentenced for caning due to the violation of the Qanun law.

On the sentence day, both of the defendants were placed on a predetermined public pitch. The process of transporting them was done by two medical personnel through an ambulance car. As the canning process is open for public view freely, children were not allowed to be viewers in this process. The caning execution was performed by a person in which both of his face and all of his limbs are covered to protect his identity by the viewers.

Before the sentenced day, the defendants, particularly the woman, demonstrated several psychological symptoms as well as a disrupted mental state. The following Table 1 displays the conditions of her psychological examination, whereas Table 2 shows her mental state examination.

Table 1: Psychological and physical observations of the patient during 3 days of pre- and post-execution

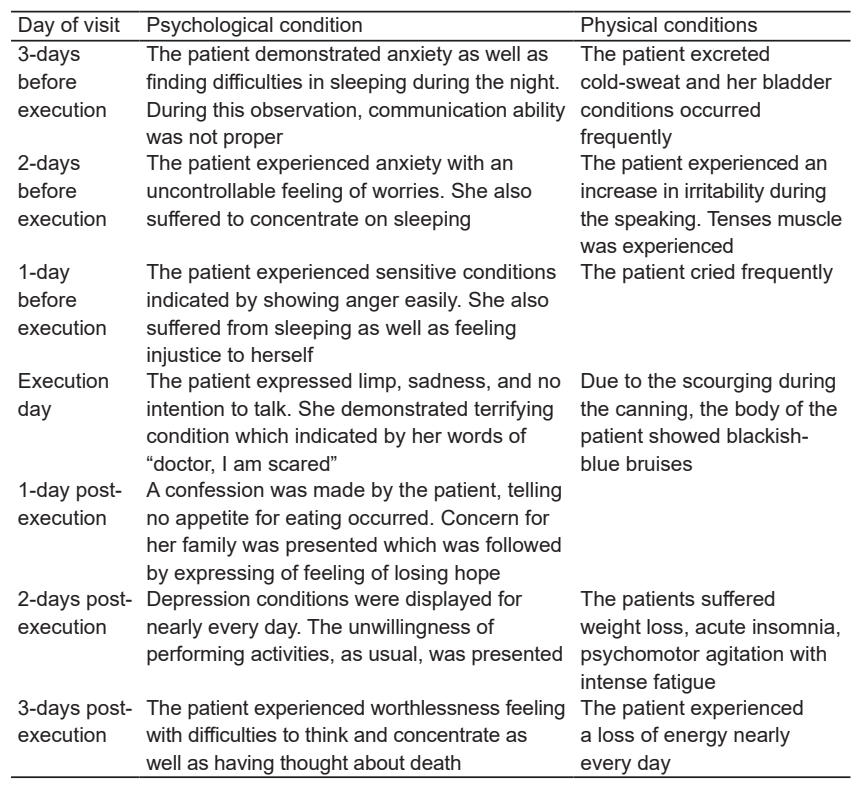

\section{Discussion}

In Qanun number 13/2003 regarding gambling practices, Article 23 Paragraph 1 states that those who violate the provisions are sentenced by caning in public for maximum 12 times and minimum for 6 times. By referring to the Governor of NAD regulation number $10 / 2005$ concerning the technical instructions of caning issued on June 10, 2005, it is mentioned in Article 2 that the implementation of caning is performed by the authorized personnel, including the Local Justice Division and the executioner. Moreover, referring to Article 1, Paragraph 10, the whipping practice is performed through a stick made of cane or rattan with a diameter between 0.75 and $1 \mathrm{~cm}$, length of $1 \mathrm{~m}$, a handle on its base. The executioner who is responsible for performing the whipping is called the Wilayatul

Table 2: Mental state examination of the patient during 3-days of pre- and post-execution

\begin{tabular}{|c|c|c|c|}
\hline Day of visit & Mental state & & Appearance \\
\hline 3-days before execution & $\begin{array}{l}\text { Affect } \\
\text { Mood } \\
\text { Other emotion } \\
\text { Speech } \\
\text { Thought process } \\
\text { Perception } \\
\text { Concentration } \\
\text { Impulse control }\end{array}$ & $\begin{array}{l}\text { Appropriate } \\
\text { Euthymic } \\
\text { Anxiety } \\
\text { Relevant } \\
\text { Good } \\
\text { Good } \\
\text { Poor } \\
\text { Good }\end{array}$ & $\begin{array}{l}\text { The patient wore on } \\
\text { a long yellow dress } \\
\text { (robe) with the } \\
\text { black color of hijab }\end{array}$ \\
\hline 2-days before execution & $\begin{array}{l}\text { Affect } \\
\text { Mood } \\
\text { Other emotion } \\
\text { Speech } \\
\text { Thought process } \\
\text { Perception } \\
\text { Concentration } \\
\text { Impulse control }\end{array}$ & $\begin{array}{l}\text { Appropriate } \\
\text { Euthymic } \\
\text { Anxiety } \\
\text { Relevant } \\
\text { Good } \\
\text { Good } \\
\text { Poor } \\
\text { Good }\end{array}$ & $\begin{array}{l}\text { The patient wore on } \\
\text { a long black dress } \\
\text { (robe) with the } \\
\text { black color of hijab }\end{array}$ \\
\hline 1-day before execution & $\begin{array}{l}\text { Affect } \\
\text { Mood } \\
\text { Other emotion } \\
\text { Speech } \\
\text { Thought process } \\
\text { Perception } \\
\text { Concentration } \\
\text { Impulse control }\end{array}$ & $\begin{array}{l}\text { Appropriate } \\
\text { Irritable } \\
\text { Anxiety } \\
\text { Relevant } \\
\text { Good } \\
\text { Good } \\
\text { Poor } \\
\text { Poor }\end{array}$ & $\begin{array}{l}\text { The patient wore on } \\
\text { a long green dress } \\
\text { (robe) and green } \\
\text { color of hijab }\end{array}$ \\
\hline Execution day & $\begin{array}{l}\text { Affect } \\
\text { Mood } \\
\text { Other emotion } \\
\text { Speech } \\
\text { Thought process } \\
\text { Perception } \\
\text { Concentration } \\
\text { Impulse control }\end{array}$ & $\begin{array}{l}\text { Appropriate } \\
\text { Irritable } \\
\text { Anxiety } \\
\text { Relevant } \\
\text { Good } \\
\text { Good } \\
\text { Poor } \\
\text { Poor }\end{array}$ & $\begin{array}{l}\text { The patient wore on } \\
\text { a long white dress } \\
\text { (robe) and a white } \\
\text { color of hijab }\end{array}$ \\
\hline 1-day post-execution & $\begin{array}{l}\text { Affect } \\
\text { Mood } \\
\text { Other emotion } \\
\text { Speech } \\
\text { Thought process } \\
\text { Perception } \\
\text { Concentration } \\
\text { Impulse control }\end{array}$ & $\begin{array}{l}\text { Appropriate } \\
\text { Irritable } \\
\text { Anxiety } \\
\text { Relevant } \\
\text { Poor } \\
\text { Poor } \\
\text { Poor } \\
\text { Poor }\end{array}$ & $\begin{array}{l}\text { The patient wore on } \\
\text { a long white dress } \\
\text { (robe) and white } \\
\text { color of hijab }\end{array}$ \\
\hline 2-days post-execution & $\begin{array}{l}\text { Affect } \\
\text { Mood } \\
\text { Other emotion } \\
\text { Speech } \\
\text { Thought process } \\
\text { Perception } \\
\text { Concentration } \\
\text { Impulse control }\end{array}$ & $\begin{array}{l}\text { Appropriate } \\
\text { Irritable } \\
\text { Anxiety } \\
\text { Relevant } \\
\text { Poor } \\
\text { Poor } \\
\text { Poor } \\
\text { Poor }\end{array}$ & $\begin{array}{l}\text { The patient wore on } \\
\text { a long white dress } \\
\text { (robe) and white } \\
\text { color of hijab }\end{array}$ \\
\hline 3-days post-execution & $\begin{array}{l}\text { Affect } \\
\text { Mood } \\
\text { Other emotion } \\
\text { Speech } \\
\text { Thought process } \\
\text { Perception } \\
\text { Concentration } \\
\text { Impulse control }\end{array}$ & $\begin{array}{l}\text { Appropriate } \\
\text { Irritable } \\
\text { Anxiety } \\
\text { Relevant } \\
\text { Poor } \\
\text { Poor } \\
\text { Poor } \\
\text { Poor }\end{array}$ & $\begin{array}{l}\text { The patient wore on } \\
\text { a long white dress } \\
\text { (robe) and white } \\
\text { color of hijab }\end{array}$ \\
\hline
\end{tabular}


Hisbah officer, who is appointed by the prosecution division.

Regarding the place of execution, Article 4 on the Governor's regulation, the caning sentence is performed in an open public area. In this section, the distance between the convicted and the executioner is explained with the distance of $0.7 \mathrm{~m}$, whereas the whips are positioned on the left side of the defendants. As the purpose is to provide deterring for the society not to violate the provisions, the execution can be witnessed by people with the attendance of both prosecutors and doctors. Consequently, public punishment could affect the defendant's emotional features with various symptoms such as anxiety, depression, and mood disorders.

The interesting finding of this case is the presence of several psychological symptoms as well as mental state conditions due to the public execution. Public judgment can shape the thought of a society based on what it is talked, in which the talking content can shape the perception of someone or even more the majority people, particularly in this caning sentence [6]. Our report showed that the terrifying mental state expressed by the patient has suggested the sentence created an intense atmosphere in the surround of the patient, which was also indicated by the unwillingness of not talking to someone. A study that compared two comments both online and public opinion polls have suggested that the self-acceptance toward comments in online website increased the awareness of being negative which led to negative attitudes [7]. As the Qanun is a sentence which is conducted publicly, it is assumed that the patient may have thought negative thoughts due to the public execution, and this was indicated by irritable mood and poor thought process mainly in the post-days of execution (Tables 1 and 2).

The patient was sentenced due to immoral activities with someone's husband. As the Qanun law stated that marital adultery is prohibited due to Islamic Sharia that shapes the behavior of communities, this violation could have been considered by the society as something that against the morality of Islam. This implies to the meaning of public enemy, as in 1-day of post-execution, the patient expressed her hopeless words which were indicated by the worries about her families, particularly after being imprisoned [8]. Islamic Sharia stated that the punishment in misbehavior of adultery is categorized into two types, which were tazir and hudud punishments, in which the hudud showed its commitment in doing the adultery before getting caught [9], [10]. Subsequently, the execution of caning sentence for this case was performed to provide educational media for the society that views the execution. In contrast, a study has reported that although the local government of Aceh intended to implement the Islamic Sharia in to achieve a well-behaved society, the people who view the caning execution perceived it more as entertainment [11], rather than educational or deterring. Our assumption might have confirmed by the expression of the patient by demonstrating a thought about death and experience of worthlessness (Table 2).

\section{The trauma of caning sentence}

Based on Table 2, the patient experienced fear and anxiety in facing the fact that she would receive a canning sentence. At that time, she could still be invited to communicate properly, even though sometimes she shed tears every time she tried to speak. Canning a sentence is not only about committing criminality but it is also considered as something against public morality. According to her family, the patient is a cheerful individual with acceptable behavior to children and ability to socialize among people very well. However, the sentence changed his personality which is demonstrated by her words about "I am not a good mother for my children" and "I have destroyed my family reputation due to my misbehavior." As a result, she feels humiliated to interact with people, particularly those in her neighborhood. Furthermore, post-trauma syndrome occurred within her which acted silently compared to her personality before. Thus, daily counseling has been performed.

\section{Conclusion}

The caning sentence is purposively carried out to provide an educational feature for the society as well as deterring effects on the actions of violating the rules of Islamic law. However, it is not only for the physical aspect that is required to consider for the defendants due to their experiences of the execution but also a consideration about the mental health condition both for the defendants as well as the societies in the time of pre-and-post the execution.

\section{References}

1. Rasyid R. Qanun Jinayat Provinsi Nanggroe Aceh Darussalam dalam Sistem Hukum Nasional; 2019. https://doi.org/10.30821/ miqot.v42i2.542

2. Darussalam G of NA. Qanun Aceh. Qanun Aceh Nomor 8 Tahun 2014 Tentang Pokok-Pokok Syariat Islam Banda Aceh: Dewan Perwakilan Rakyat Aceh; 2014. p. 1-15. Available from: https:// doi.org/10.31219/osf.io/3uenb

3. Tran TD, Kaligis F, Wiguna T, Willenberg L, Nguyen HT, Luchters S, et al. Screening for depressive and anxiety disorders among adolescents in Indonesia: Formal validation of the centre for epidemiologic studies depression scale-revised and the Kessler psychological distress scale. J Affect Disord. 2019;246:189-94. https://doi.org/10.1016/j.jad.2018.12.042 PMid:30583144 
4. Muñoz-Navarro R, Cano-Vindel A, Medrano LA, Schmitz F, Ruiz-Rodríguez P, Abellán-Maeso C, et al. Utility of the PHQ-9 to identify major depressive disorder in adult patients in Spanish primary care centres. BMC Psychiatry. 2017;17(1):291. https:// doi.org/10.1186/s12888-017-1450-8

PMid:28793892

5. Christiani Y, Byles J, Tavener M, Dugdale P. Socioeconomic related inequality in depression among young and middle-adult women in Indonesia's major cities. J Affect Disord. 2015;182:7681. https://doi.org/10.1016/j.jad.2015.04.042 PMid:25978717

6. Neubaum G, Krämer NC. Monitoring the opinion of the crowd: Psychological mechanisms underlying public opinion perceptions on social media. Media Psychol. 2017;20(3):502-31. Available from: https://www.tandfonline.com. [Last accessed on 2020 Oct 03]. https://doi.org/10.1080/15213269.2016.1211539

7. Lee MJ, Chun JW. Reading others' comments and public opinion poll results on social media: Social judgment and spiral of empowerment. Comput Hum Behav. 2016;65:479-87. https:// doi.org/10.1016/j.chb.2016.09.007

8. Orrell K. Swansong: Can hope survive an indeterminate prison sentence? Br J Psychother. 2019;35(3):373-81. Available from: https://www.onlinelibrary.wiley.com. [Last accessed on 2020 Oct 03]. https://doi.org/10.1111/bjp.12465

9. Nurhayati J. The implementation of criminal act of adultery. Adv Soc Sci Educ Humanit Res. 2018;162(11):46-9.

10. Moulia N. The Position of Defendant's Statement in the Proof of Adultery Case (The Analysis of Syar'iyah Court Verdict Banda Aceh). Berlin: Atlantis Press; 2020. p. 121-4. Available from: https://www.atlantis-press.com/proceedings/ icolgis-19/125936092. [Last accessed on 2020 Oct 03]. https:// doi.org/10.2991/assehr.k.200306.195

11. Fadlia F, Susilawati N, Ramadani I, Sari N. Deterring or entertaining? Can the caning punishment execution in aceh meet its objective? Mazahib. 2020;19(1):41-78. Available from: https:// www.journal.iain-samarinda.ac.id/index.php/mazahib/index. [Last accessed on 2020 Oct 03]. https://doi.org/10.21093/mj.v19i1.2055 